\title{
2021年度木材劣化診断士資格取得検定講習の 開催報告
}

\section{1.はじめに}

2021年 8 月 31 日，2021年度木材劣化診断士資格 取得検定講習会（以下，講習会とする）が東京神 田にて開催された。標記講習会は，原則として毎 年 1 回開催されており, 新たな木材劣化診断士に 必要な基礎的な知識に関する講習を行い, 講習後 に実施する筆記試験および後日に提出するレポー 卜課題により木材劣化診断士を認定している。

木材劣化診断士は，2007年 1 月31日に規程が制 定され，木材劣化診断士委員会の下に誕生した。 今年で14年が経過したことになる。発足以来これ まで，京都大学・藤井義久教授が初代委員長とし て制度を維持してこられたが，本年度より筆者が 二代目の委員長を帱命した。責任の重さに身の引 き締まる思いである。読者の皆様には改めてご挨 拶申し上げる。

本稿は，委員長交代をきっかけとして木材劣化 診断士制度について改めてご紹介させていただく とともに，8月に開催された講習会について，新 型コロナウィルス感染拡大下に昖ける準備も含め てご報告する。

\section{2. 木材劣化診断士制度について}

\section{1 制度の概要}

木材劣化診断士制度は，木材保存協会 -木材劣 化診断士委員会が管理している任意資格である。 認定された木材劣化診断士が，使用下にある保存 処理木材をはじめとする種々な木質材料の劣化診 断を行い，この結果に基づいてこれらの材料が適 切に維持管理され，耐久性の向上が図られること
原 田 真 樹*

を目的としている。本制度はとりわけ保存処理木 材（注入処理）の製造者が，使用下にある木材製 品の維持管理を行うことにより，製造者としての 社会的責任を果たすための活動の一環として開始 されたものだが，現在は範囲を拡大し，一般住宅 や外構施設における木部の腐朽や蟻害および虫害 （生物劣化）の診断が担えるレベルの技術を習得 することを目的としている。

\section{2 講習会および制度の変遷}

発足当時は上記の通り木材保存士を対象として いたため, 資格検定試験の受験資格を木材保存士 であることとしていたが，国土交通省における 2010年代の既存住宅の建物状況調査（インスペク ション）に関する制度制定等の動きが追い風とな り,建築士の資格を有する者の受講生が増加した。 これを受け，2010年から「一級・二級・木造建築 士」および「その他本会が認める者」が受験資格 に追加された。更に2011年からは建築士会 CPD 認定講習となり ${ }^{2)}$ ，さらに建築士の受講拡大を指 向した改革が行われた。

講習の日程について, 発足当初から 7 年間 (2013 年まで）は 2 日間に亘って実施されていた。木材 保存士と建築士という背景知識の異なる受講生を 対象としたことから，2 日間のプログラムについ て，それぞれの資格に対応した選択制の時間割編 成としたこともあった。しかしながら受講生への 負担等も考慮し，2014年以降現在まで，内容を圧 縮して講義から筆記試験までを 1 日で完了するプ ログラムが定着している。

* 国立研究開発法人森林研究・整備機構 森林総合研究所 


\section{2021年度木材劣化診断士資格取得検定 講習会}

\section{1 講習会の開催形式と準備に関する議論}

木材劣化診断士の資格発行は11月と決まってい るため, 講習会は遅くとも 9 月中には開催する必 要があった。しかしながら，ちょうどこの時期は 新型コロナウイルスの感染拡大が収まらず，開催 予定地である東京都には緊急事態宣言が発出（延 長）されている状態であったことから，開催形式 を対面とするかオンライン形式とするか，そもそ も開催して良いものかということも含め事前に才 ンライン会議を開催して議論した。会議では, 当 講習会の特色の一つである実習の効果がオンライ ンでは十分に発揮できない, 同じくオンラインで は筆記試験について透明性・公平性の確保が難し い，延長という選択肢は資格発行時期との関連で 困難である等の意見が出された。これらの意見を 踏まえ，8月31日(火)に予定通り神田の会議室にお いて対面形式にて実施することを決定した。

\section{2 講習会当日の様子}

受講申込期限（8月20日）までにあった17名に ついて，3名の予定者から新型コロナウィルスの 感染拡大を理由とするキャンセルがあったため, 出席予定者は14名となった。このうち，申込締め 切りから前日までのキャンセル 1 名, 当日キャン セル 1 名により, 当日の講習参加者は 12 名であっ た。受付に扔いて受講者全員の体温検査 (非接触) を実施して平熱であることを確認するとともに， 会場への出入りの際には手指消毒をすることをお 願いした。

各講義においては，各講師はフェイスガード等 を着用し(写真 1 ), 可能な限りパーティション を介して講義するよう留意した。また，実習を伴 う講義（2次診断）では, 講師はマスクを装着し, 受講生は軍手を着用した。各講義の概要を以下に 示す。

(1)ガイダンス（所要時間 : 10分, 講師 : 筆者)

木材劣化診断士制度の概要紹介である。本制度 が日本木材保存協会の任意資格であること，劣化 診断士は対象とする木材の劣化の種別・程度・範 囲を客観的に評価するとともにその原因について コメントすることが求められるが，構造物の寿命

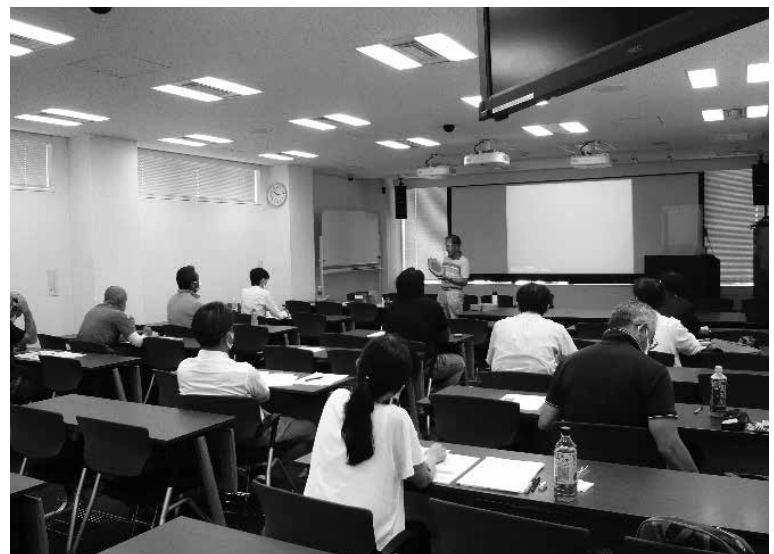

写真 1 講義の様子

や危険度の断定的な評価はできないこと, 改修な どを誘導するような診断はやってはならないこ と, 劣化診断士になるには筆記試験と論述 (レポー ト）試験を受ける必要があること等について，ス ライド（Power Point）と配付資料とを用いて説 明した。

(2)木質建材 (50分, 横浜国大名誉教授・矢田茂樹 氏)

木材についての基礎知識から木質建材の現場で の見分け方など，幅広い内容についての講義であ る。資料は当日配付資料と講師が当日持ち込む豊 富な教材である。中でも生きたシロアリ（もちろ ん密封容器にて展示）は毎回受講生に人気のアイ テムである。講義は樹木から木材の組織構造・物 性に関するものと，木質建材に関する内容の，大 きく2つに分かれる。前者においては，木材の組 織構造や木材の変形や割れのメカニズム（このと きに講師が使用する扇の教材には毎回感激する), 含有水分状態掞よび木材保存処理の概要に関する 説明があった。後者では，木質材料の種類とその 出現に関する年代的な特徵（この情報は現場での 築年数および維持管理の推定に大きく役立つ）に 関する説明があった。最後に講師が現場で実際に 体験した難しい判断事例等の紹介もあり, 基礎か ら実用的な内容まで幅広い内容であった。

(3)住宅インスペクション概要 (60分, 株式会社 白國ケアデザイン・白國喜夫氏）

木材劣化診断士と関連の深い国土交通省「既存 住宅インスペクション・ガイドライン」(2013年 6 月）に関する解説と実践に関する講義である。 講義は，上記インスペクション制度に基づいたイ 
ンスペクションの方法抒よび内容，調査業務の手 順，報告書の作成等についてであり，スライドお よび当日配付資料によって学んだ。(2)が木材から のアプローチで劣化診断を考えるものであるなら ば，本講義は建築の立場から劣化診断を考えるた めの講義といえよう。インスペクション制度に基 づく一次的インスペクションは, 劣化診断士制度 における 1 次診断に相当するもので，アプローチ は異なるが基本的な調查方法やその進め方につい ては共通する部分が多く，また，依頼主への配慮 （診断時の服装や床下点検口からの出入りにおけ る配慮等）や報告書の事例等，講師の体験に基づ く内容の濃い講義であった。

(4) 1 次診断 (90分, 京都大学大学院教授・藤井義 久氏）

午後からの $2 つ の$ 講義は，木材劣化診断におけ る実務的な内容を学ぶ内容となっている。このう ち， 1 次診断では，劣化の種別として，腐朽・蟻 害・虫害を取り上げ，現場での被害例や判別の仕 方，各劣化における木材がアタックされるメカニ ズム等を学んだ。本講義はテキストの写真ページ およびスクリーンでのスライドをフル活用した内 容であり，木材の腐朽のメカニズムから腐朽材の 被害状況, シロアリの生態や蟻害の現場について, その様子だけでなく，腐朽の原因となる水分の経 路やシロアリの侵入経路等，劣化診断では被害の 状況だけでなくその原因も探ることが重要である ことを再認識させてくれる内容であった。実際の 劣化診断業務に打いて大部分を占め，かつ，必須 業務ともいえる 1 次診断を実施するにあたり，極 めて重要な実践的な知識を学ぶ講義であった。

\section{(5) 2 次診断（80分，矢田茂樹氏，筆者)}

木材劣化診断における 1 次診断が主として人間 の感覚（視覚，触覚，聴覚，ときには嗅覚）によ って判断するのに対し，2次診断は専用機器を用 いた機器診断である。本講義では，劣化の程度を 推定する物理的指標として含水率，衝撃ピン貫入 抵抗，超音波伝播速度，せん孔抵抗を取り上げ， それぞれを測定するための専用機器の原理や使い 方について，実機によるデモと受講生自身による 体験も含んだ内容であった(写真 2 )。教材は毎回, 京都大学に保管されている褐色・白色腐朽材（菌 糸付!), 被害程度の異なる蟻害材, 内部・外部
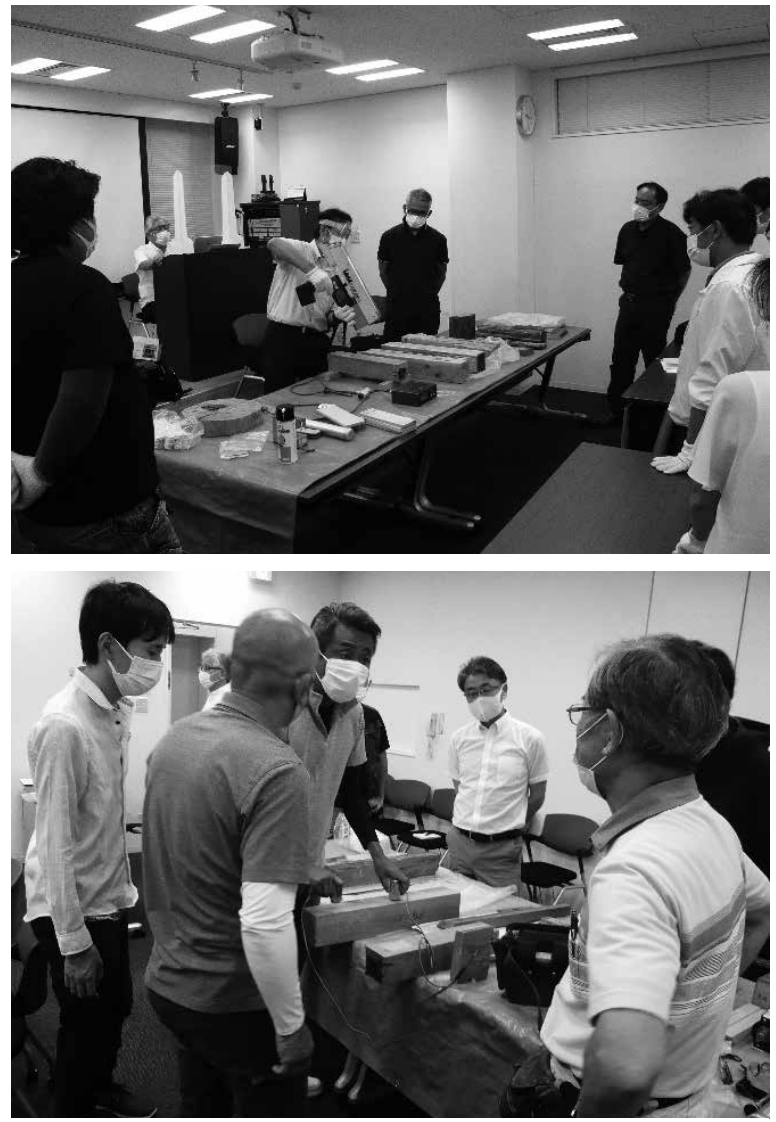

写真 $2\lceil 2$ 次診断」実習風景

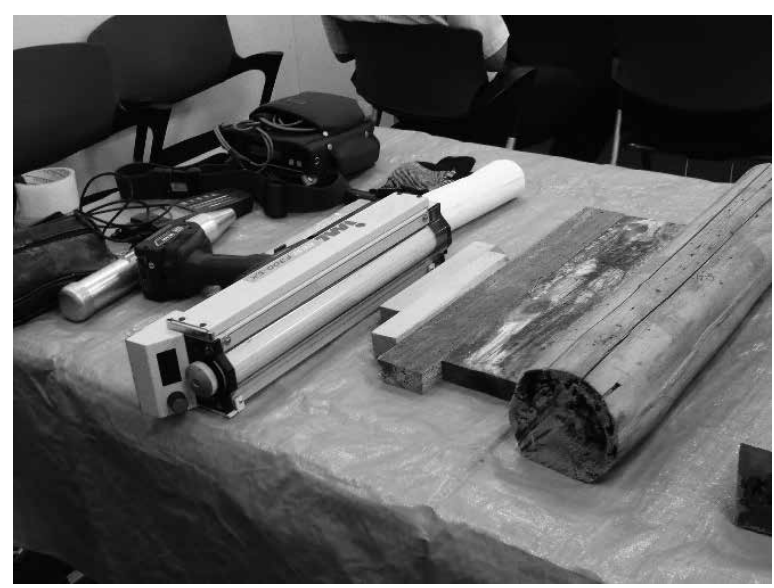

写真 $3 「 2$ 次診断」実習用教材及び測定機器

腐朽材等であり，これらの教材に対し，上記測定 機器を用いて実際に数值を求める体験をする内容 であった（写真 3$)$ 。この体験が本講習会の他の 診断制度講習にはない特徵の一つとなっている。

(6)レポートの書き方（10分，藤井義久氏）

木材劣化診断を業務として受ける場合, 成果物 として報告書を提出する必要がある。木材劣化診 断士制度ではこれを背景として，基礎的知識を問 う筆記試験の他に実際に身近にある物件の劣化診 
断を実施してそのレポートを提出するという論述 試験を課している。本講義ではそのレポートを書 くための基礎的事項について解説する。講義では, 対象物件名や診断年月日, その日の天候を必ず記 すことや, 現場用のチェックシート等について, テキストによる解説があった。

\section{(7)筆記試験 (30分)}

木材劣化診断士の資格を取得するためには，資 格検定講習会を受講し，基礎的な知識を問う筆記 試験を受験し, かつ, 身近な物件の劣化診断結果 を報告書の形にまとめたレポート課題を提出する 必要がある。筆記試験はテキスト類の持ち込みは 不可である。この筆記試験結果とレポート課題を 合わせて合否判定を行う。

\section{4. 結びに代えて}

本稿では，木材劣化診断士の資格制度について 概観し, 今年度実施した資格取得検定講習の概要 について紹介した。新聞等の報道を待つまでもな く，木質材料を用いた構造物の安全性確保につい ては,これまで以上に国民の関心が高まっている。 最近も，国土交通省が木質系材料の維持管理に関 する指針を準備しているという報道があった。木 造住宅等を対象とする診断資格は数多く存在して
いるが，これらに対し木材劣化診断士は，木材そ のものの劣化を正しく判定し, その原因を推定で きる人材を輩出するという点において, 他とは一 線を画す資格であると思う。本稿をきっかけとし て, 木材劣化診断士の重要性について再認識いた だければ望外の喜びである。

\section{謝辞}

今回の講習実施にあたっては, 準備の段階から 藤井先生, 矢田先生, 鈴木氏に多くの示唆をいた だいた。また講習会当日, 白國先生には困難な中, 大阪から神田まで来ていただいた。これら講師お よび事務局の支えがなければ講習会の実現は難し かった。ここに記し, 改めて深甚なる謝意を表す。 さらに, 新型コロナウィルスの感染拡大状況が 日々変化しているなか, 受講を決断いただいた受 講生各位にも御礼申し上げる。

\section{引用文献}

1 ) 藤井義久:木材の劣化診断技術の課題と展 望, 木材保存, 34, 256-260 (2008).

2) 日本木材保存協会事務局：公益社団法人日本 木材保存協会のここ10年の歩み, 木材保存, 44, 212 (2018).

(2021.10.10受付) 